\title{
Currency and Settler Colonialism: the Palestinian Case
}

\section{Serena Merrino}

SSEES, University College London, London UK

serena.merrino@ucl.ac.uk

Dr Serena Merrino is a Ph.D. graduate of the SOAS School of Finance and Management and is currently a Research Fellow of the United Nations University (UNU-WIDER) and the South African Reserve Bank (SARB). She is also a Teaching Fellow at the UCL School of Slavonic and Eastern European Studies in London, UK. 


\section{Currency and Settler Colonialism: the Palestinian Case}

This paper aims to shed new light on the international dimension of monetary power by exploring currency policy as a systematic tool of settler colonialism. The latter is defined as a mode of domination whereby an exogenous hegemonic power aims to displace and dispossess the native society in order to establish a new permanent homeland. These arguments are developed by exploring the case of Israeli currency circulation in the occupied Palestinian territories. To this purpose, the heterodox critique of the classical theory of money is employed to provide a fresh geopolitical reading of the origins, evolution, implications, and continued viability of a so-called 'settler currency.' It is found that Israel's settler colonial project has been expedited by the enforced shekelization of the oPt, in that the latter not only acts as a barrier to industrialization and economic liberation in line with other hegemonic institutions, but also offers a sophisticated tool for coercion that directly assists the hegemon's political ends. It follows that a settler colonial currency represents a multifaceted vehicle that facilitates the settler state's reproduction.

Keywords: money, power, colonialism, currency policy, hegemony, Palestine.

Subject classification codes: B520, E50, F540 


\section{Introduction}

The Palestinian economy of the West Bank and Gaza Strip has employed the Israeli currency since the outset of Israel's military occupation in 1967 (Pasch, 1992). The process by which a foreign currency - in this case the Israeli shekel - circulates domestically to serve some of the conventional functions attached to money is an example of currency internationalization, or substitution. Mainstream economic theory legitimized the idea that the shekelization ${ }^{1}$ of Palestine would foster economic and financial integration within the currency area and sustain the convergence of the small, low-income client economy with the advanced issuer country (Dellas and Tavlas, 2009), ultimately bolstering a positive environment conducive to political conciliation between the parties involved. Although international organizations have explicitly supported this view on the ground (see for instance World Bank, 1993; 2002), the expected gains are still far from tangible. As a result of lower transaction costs and enhanced bilateral commerce in the currency area, Israel is the largest trade partner of the occupied Palestinian territories (hereafter, oPt). However, the Palestinian economy suffers from a persistent current account deficit that must be sustained by unilateral transfers: in 2018, net imports of goods and services from Israel accounted for \$2.7 billion (PCBS, 2019).

Furthermore, inflation imported from Israel through trade has a severely detrimental effect on Palestinians' purchasing power, while persistently high interest rates on loans discourage the mobilization of savings for productive investment. Lastly, the absence of effective countercyclical policies shifts the adjustment burden onto the working class through an increased unemployment rate that approximated 30 percent in 2019. Intensified economic activity in the currency area has ultimately produced a precarious state of liberal peace, as political stability relies on undermining Palestinian society's capability to challenge Israeli rule in pursuit of its own rights.

It is acknowledged in no uncertain terms that the growing economic divergence between the oPt and Israel is caused by a complex system of restrictions that have been put in place by Israeli authorities over the decades (Arnon, 2007; UNCTAD, 2009; 2017). While Israeli occupation of the Palestinian territories has never been driven by economic motives per se, it is widely understood as serving the Israeli settler-colonizing project in the region (Veracini, 2013). Veracini defines settler colonialism as a specific mode of domination that is especially concerned with space, "where colonisers "come to stay" and to establish new political orders for themselves, rather than to exploit native labour' (ibid., p. 1). He also stresses that settlers' capacity to establish a new society 'is inevitably premised on the possibility of controlling and dominating indigenous peoples' (ibid., p. 2).

Most research conducted in this field deals with shekelization as only a cosmetic piece of a bigger puzzle of lop-sided economic ties that strengthen a dependency paradigm (among others: Naqib, 2003; Arnon and Bamya, 2015). Among the few empirical studies that focus on the Palestinian monetary system, some speculate over the optimality of the current regime (Arnon and Spivak, 1996), while others look into the viability of a future arrangement (see, for example: Sadeh, 1997; Erickson von Allmen and Fischer, 2001; Cobham, 2004; Beidas and Kandil, 2005; Armstrong et al., 2007; Wazir et al., 2011; Toffano and Yuan, 2019). However, all these assessments are conducted in terms of purely economic efficiency, completely or partially overlooking the ongoing colonization motif and treating power

\footnotetext{
${ }^{1}$ The entire process of currency substitution is denoted 'shekelization' by virtue of the shekel currently issued by the state of Israel. It must be noted, however, that the first currency to be introduced in the oPt in 1967 was the Israeli lira, which was legal tender from August 1948 until February 1980, when it was replaced with the old shekel. The new shekel (NIS) became the official currency in January 1986.
} 
asymmetries as an exogenous element that distorts an otherwise functional macroeconomic system. By 'promoting the idea that economic policies are objective and disinterested processes operating above power relations' (Hanieh, 2016, p. 32), the dominant approach systematically fails to embed the political roots that determine economic phenomena in the first place, instead reproducing the structures of hegemony as viable future policymaking. Along these lines of thought, more critical scholarship develops the argument that neoliberalism serves Israel in infiltrating the Palestinian political economy space (see Farsakh, 2008; Hanieh, 2008; Haddad, 2016; and Hanieh, 2016). Yet shekelization is not conceived as a fundamental tool used by the colonial regime to exert political influence.

Drawing on existing works on the international political economy of currency from both the realist and colonial studies traditions, this paper aims to shed new light on the political implications of currency internationalization. In particular, it attempts to surpass the limitations of the state-centric paradigm of domination and expand the colonial perspective with respect to currency policy by exploring the experience of shekelization in the oPt as a systematic tool of settler colonialism. It will be argued that the expansion of a currency's domain beyond its national jurisdiction can provide another mode of economic intrusion that facilitates the dispossession of the client country's sovereignty, and as such a settler currency should be distinguished from previous conceptual categories such as international or colonial currencies (e.g. the US dollar and the CFA franc). Settler colonial projects founded the modern societies of the Americas (in the 1600s), Australia and New Zealand (in the 1800s), and more recently South Africa, the Philippines, Taiwan, and Northern Cyprus. In all the aforementioned cases, settlers subjugated the natives through multiple forms of violence. However, in none of these cases - to the best of my knowledge - has currency policy been formally investigated as an oppressive tool used to maintain settler hegemony over the natives. $^{2}$

With these preliminaries out of the way, the next section proposes a theoretical and methodological critique of the State and Credit theories of money (Mitchell-Innes, 1914; Knapp, 1924) as an analytical paradigm to disentangle the nexus between currency policy and international politics. The ability of extant literature on international monetary power to conceptualize international currencies as instruments of political influence, economic oppression, or displacement of the client country will also be reviewed. In Section 3, Palestinian shekelization is presented as a path-dependent monetary system, contingent on (i) the currency-issuing state's authority; (ii) the institutional network built around the hegemonic currency; and (iii) the currency's competitive force. Section 4 investigates some of the implications of shekelization, first by looking at its macroeconomic and distributional effects and then by casting an eye on the use of currency policy as a coercive tool to promote Israel's political ends. On these grounds, the paper will eventually conclude by characterizing the role of currency in settler colonial projects and commenting on the wisdom and likely future course of this monetary regime in the Palestinian case.

\section{The Nature of International Currencies: Theoretical Perspectives}

\footnotetext{
${ }^{2}$ In the majority of settler colonial projects aimed at the extermination of natives, as in the Americas and Australia, the local polity was not economically advanced and settler control could be achieved beyond monetary pressure. In cases where the settler society is separated from the natives, as in Northern Cyprus, South Ossetia and Abkhazia, and the Sahrawi Arab Democratic Republic, the latter has not accepted the use of the settlers' currency.
} 
The fundamental function attached to money by the classical theory of metallism is to measure the relative prices of goods and services across markets and time in order to simplify exchanges. If the origin of money is thought of as driven by private sector efficiency, the spatial determination of currency areas should be analogously assessed over value-free transaction costs and macroeconomic stability. ${ }^{3}$ An alternative theory - presented in 1914's The Credit Theory of Money by Alfred Mitchell-Innes and 1924's The State Theory of Money by George Knapp - argues instead that money is legal in nature and that its value is the enacted outcome of debt relationships (Fields and Vernengo, 2013). Thus, if attention is diverted away from mathematical formalization towards a systems view of the economy being set in a social and ecological environment, the analysis of currency internationalization 'has almost nothing to do with economic costs minimization and almost everything to do with considerations of history, institutions, and political sovereignty' (Goodhart, 1998, p. 409). When the state promises to accept a unit of account for the repayment of tax obligations, it is providing value to a fiat currency regardless of the metal coins are made of: 'It is not the thing that matters, but the ability of one section of the population to impose its standard on the majority, and the institutions through which that majority accepts the will of the minority' (Henry, 2004, p. 96). Put differently, taxes create demand for the currency previously established by the state as the unit of account, and as such they represent the primary source of legitimacy of the legal tender.

From this perspective, the international expansion of a currency's domain must result from a hierarchical relationship between issuing and client states. In this respect, Strange's (1971) classification of international currencies can be interpreted as depending on the form of foreign influence that client countries are bound to. Top currencies are those like the US dollar and euro, whose international circulation follows a Darwinian process of competition that reflects the issuing state's global market leadership (Cohen, 2015). In his book 'Currency Power,' Cohen (2015) treats currency substitution as a dependent variable determined by transaction costs and the volume of cross-border transactions. Fields and Vernengo (2013) see the monetary hegemon as the issuer of a currency-denominated asset free of the risk of default, and on this basis they argue 'that the euro is not a credible challenge to the dollar' ( $p$. 14). Strange (1971) also identifies so-called master currencies, the use of which is imposed by a foreign state that holds the de facto monopoly of force over other polities, including sovereign entities. Examples of master - or colonial - currencies are the CFA franc in francophone Central Africa and sterling in British colonies in East and Southern Africa. The foundation of master currencies is therefore colonial: the hegemonic state enforces the use of the currency of its choice by imposing obligations (e.g. taxation or products) on the client country, as it does within its own national jurisdiction.

In fact, hegemonic rule is often accomplished through the prevailing institutional structure rather than by using direct forms of coercion. ${ }^{4}$ Institutions are the implicit rules of the game that reflect the actual allocation of decision power and determine cross-country structural asymmetries (Robinson et al. 2005). Cross-border economic institutions (e.g. finance, trade, labor, and fiscal policies) therefore promote the hegemonic currency internationally, while the international currency simultaneously advances those institutions and so hegemonic rule. This mechanism resembles the circular and cumulative causation concept developed by Myrdal (1956). However, although 'state money is the highest form of money in that it can be used to

\footnotetext{
${ }^{3}$ The 'Optimal Currency Area' literature draws on this view. See Dellas and Tavlas, 2009.

${ }^{4}$ Strange (1988) defined 'structural power' as the ability to establish institutions to one's own advantage.
} 
pay tax obligations and it is also generally acceptable for discharge of private debts,' it is 'in perpetual competition with other forms of money, and the boundary of use fluctuates with legal and technological developments' (Palley, 2014, p. 2), such that the market's competitive forces also contribute to determining the geographical evolution of currencies.

If currency internationalization rebalances structural power by reinforcing hegemonic rule, international monetary relations will by their own nature produce debt relationships and inequalities. In effect, wealth redistribution at both macro- and micro-levels is found to be a consequence of the expansion of top currencies such as the euro (Cohen, 2015), as well as of master currencies such as British sterling and the CFA franc (Nyamunda, 2017; Taylor, 2019). Also, currency internationalization provides the issuing state with increased control over one of the most vital means in economics, and so is a direct tool of coercion beyond its national jurisdiction. This argument is based on the fact that the amount of foreign currency available to any particular economy is the outcome of cross-border capital and trade flows or multilateral agreements, which in turn are affected by diplomatic relations with the issuing state. The political implications of dollarization for countries that have opposed US rule have been widely discussed by scholars of the realist tradition such as Kirshner (1995), Cohen (2003; 2015), Broz and Frieden (2001), and Frieden (2003). In particular, Kirshner (1995) represents an invaluable contribution to the study of intentional monetary power in the last century. In 'Currency and Coercion' he reviews a number of case studies to explore the use of currency manipulation for political advantage and the imposition of monetary dependence paradigms. However, his book offers only three examples of systemic disruption through currency policy, including the United States' monetary war on Panama in the late 1980s, and none of these is classified as successful from the agent's perspective. More importantly, Kirshner's (1995) thorough and fascinating historical analysis denies both the exploitative and racialist nature of colonial rule and the possibility of class mobilization to overthrow it.

A materialist approach to the study of international currencies is present in African colonial studies, which remarks on the use of economic and monetary policy for racial and economic exploitation. In this context, Mwangi (2010) explores how the aesthetics of currency design in colonial Africa evolved alongside questions of race and class. While illustrations on notes in francophone Africa reproduced the modernizing symbols of colonial development, paternalistically contrasted with the 'tribal' nature of indigenous Africans, the design of sterling in British colonies initially refused 'to acknowledge, even indirectly, an African presence' at all. Nyamunda (2017) reveals instead the mechanism through which colonial currency policy was managed in an attempt to bolster imperial post-war reconstruction. He writes: 'Britain's efforts to resuscitate confidence in a sterling currency that was losing its previously leading position in global finance by consolidating its African colonies into the discriminatory sterling area caused problems in Southern Rhodesian trade relations, especially with South Africa - her largest trading partner. [...] Southern Rhodesia's financial considerations were exclusively designed for a settler state with Africans only accommodated for labor provision' (p. 82). Nyamunda's (2017) historical account also provides evidence of how currency independence then took central stage in the delinking of the white settler minority from the parent economy. Once they had established a solid economy with export capacity, British Africa severed colonial currency links with independence. For example, the East African Currency Board fell in 1965 because the new emerging states - Kenya, Tanzania, and Uganda - would not agree to renounce monetary sovereignty. By contrast, Taylor (2019) focuses on describing how postcolonial sovereign states forced to remain in the CFA franc zone are subjected to a monetary system that is directed from France to its own economic and political advantage (e.g. most foreign exchange 
reserves of CFA members must be held in Paris and can be invested by the French Treasury with no gain for Africans; France benefits from preferential access to cheap commodities through exchange rate overvaluation; 14 African countries depend on French aid). Taylor argues that the CFA is a classic example of a policy that subordinates the developmental potential of client economies in order to expand the leading country. Finally, Taylor (2019) mentions the importance of the agency of African elites in the perpetuation of dependency relations with France, thus acknowledging that the colonial monetary architecture is ultimately secured by a transnational class of privileged actors motivated by the pursuit of personal profit.

As a continuation to this strand of literature on the monetary dimension of domination, the next section will describe the origins and functioning of the Israeli currency in the oPt to examine the use of monetary policy to pursue the settler colonial project. It will be demonstrated how the internationalization of the hegemonic currency can support a settler community seeking to dominate a native society with the ultimate purpose of expropriating land and creating a new exclusive polity, rather than in pursuit of economic gains and wealth.

\section{Origins and Evolution of a Settler Colonial Currency}

\subsection{Hegemony}

Interestingly enough, the lack of a proper state apparatus or democratized institutions in the Palestinian territories has repeatedly offered foreign powers fertile ground to establish their rule. By securing parental control over domestic monetary tools, currency policy has proven a constitutive step for colonial projects in different eras. When Britain took over Palestine after the First World War, a fully independent currency board was created by the British Ministry of the Colonies in 1926 to issue the Palestine pound, which was backed by an equivalent amount of sterling held in London (Ottensooser, 1955). With the birth of the state of Israel in 1948, the rest of the British Mandate of Palestine was forcibly divided between the Hashemite Kingdom of Jordan, which took over the West Bank and East Jerusalem, and the Egyptian army, which gained control of the Gaza Strip. The currency board was dissolved under the supervision of the British Colonial Office, although its assets were never returned to the Palestinians. ${ }^{5}$ In the meantime, 59 million Palestine pounds in circulation were progressively replaced by the Israeli lira across the newborn state, by the Jordanian dinar in the West Bank, and by the Egyptian pound in the Gaza Strip. Similarly, after Israel captured the West Bank and the Gaza Strip during the $N a k s a^{6}$ in 1967 , the Israeli lira was declared legal tender and a series of military orders were issued that facilitated its diffusion in the occupied regions (see next section).

As a response to the malaise awakened by the first intifada, in 1993 the Oslo accords eventually admitted the Palestine Liberation Organization and the Palestinian Authority (PA) as self-governing bodies with juridical recognition and full responsibility for governing the West Bank and Gaza Strip. Under this renovated political configuration, in April 1994 the Palestine Liberation Organization and the government of Israel signed the Paris Protocol on Economic Relations (PP), regulating bilateral trade, labor, and fiscal and monetary policy.

\footnotetext{
${ }^{5}$ The Palestine Currency Board's reserve funds in London 'represented over one-half of all Palestinian sterling balances $[\ldots]$ an essential part of the national capital of Palestine because they were built up by export surpluses in the past' (Palestine Papers, 2008).

${ }^{6} \mathrm{Al-Naksa}$ is an Arabic word (النكسة), literally meaning 'the setback,' referring to the displacement that followed the Six-Day War.
} 
With regards to the latter, the Protocol formalized the currency substitution process enforced in 1967 by recognizing the New Israeli Shekel (NIS) as the official currency of the Palestinian Territories. ${ }^{7}$ Although the Paris Protocol established the Palestinian Monetary Authority to regulate and supervise the domestic banking sector, interest and exchange rate decisions remained under the exclusive control of the Bank of Israel.

Behind the façade of fair diplomacy, the newly formed PA never gained de facto statehood. Instead, the Protocol legally incorporated Israeli rule into the prevailing economic structure and ensured that its fiat money would ultimately be acceptable in the discharge of the legal obligations imposed on the occupied areas. As a matter of fact, the Palestinian delegation that was invited to the Paris negotiation table by the French foreign ministry consisted of around 40 people with no clear strategy over formulation of the protocol, while there were hundreds of Israeli representatives, ${ }^{8}$ whose decisions were informed by an $a d$ hoc committee of experts (Arnon and Weinblatt, 2001, p. 295). Although the Palestinian delegation in Paris explicitly demanded an independent national currency, it was not well prepared or represented enough to effectively challenge its counterpart's proposal (Levin, 2007).

From the historical account, it emerges that the decision to adopt the Israeli currency was not made by a benevolent social planner, weighing costs and benefits based on standard economic models: a point observed already by Arnon and Spivak (1996). The new anchor currency was not replacing an inconvertible, irremediably weak local currency unit; in fact, both the Jordanian dinar and the Egyptian pound were steadily pegged to British sterling at the time. The new currency was not even renowned as strong and competitive, given that the newborn state of Israel was still relatively unstable. Nevertheless, neoclassical models developed during the 1990s had introduced the idea that independent central banks in developing countries could attract capital and enhance finance-led growth by reducing policymakers' incentives to stimulate the economy above equilibrium (Barro and Gordon, 1983). On these grounds, international organizations persuaded stakeholders that shekelization would be Palestine's optimal economic choice. Haddad (2016) provides numerous details of the World Bank's involvement 'in the second (Paris) meeting of the Multilateral Working Group on Economic Development [...] a mission it was tapped to perform by the US State Department' (p. 63). In a six-volume report published to guide negotiations in 1993, the World Bank emphasized that 'the most precious commodity of macroeconomic management is credibility, something that is hard to earn, but can be obtained by being in a currency union with a disciplined core or by establishing a track record of prudent macroeconomic, especially fiscal, management. The Occupied Territories do not have such a history' (World Bank, 1993, p. 6).

How these events unfolded demonstrates that, analogous to other cases of international money, the shekel's circulation across the Palestinian territories is rooted in the military and cultural $^{9}$ expansion of the Israeli state's authority. In contrast to the internationalization of a

\footnotetext{
${ }^{7}$ Besides the Israeli shekel, the Jordanian dinar and the US dollar are also accepted as legal tender in the oPt, although they are mostly used to denominate financial or real assets (see Section 3.4).

${ }^{8}$ Interview with Dr Samir Abdullah, a member of the Palestinian delegation that negotiated the Paris Protocol and currently Director of Research at the Palestine Economic Policy Research Institute (MAS), based in Ramallah.

${ }^{9}$ As first theorized by Antonio Gramsci, the expansion of a 'hegemonic culture' shapes beliefs in persuasive ways and perpetuates the dominant ideology by normalizing certain concepts that would
} 
top currency (e.g. dollarization in Latin America), it emerges that the foreign currency-issuing state has actively upheld the use of its own legal tender by directly intervening in domestic monetary matters, which makes the Israeli shekel in Palestine an example of master currency like the CFA franc and British sterling in Central Africa (Strange, 1971). For instance, the Paris Protocol not only advises on how to maintain central banking cooperation between the parties, but also debars the PA from issuing its own currency without prior agreement from Israel (PP, 1994, Article IV.10b). Since 1967, increased use of the Israeli currency - from unofficial to official and from partial to full - has been clearly determined by the advance of the Israeli occupation in pursuit the appropriation of Palestinian land. In July 2020, the latter has gained formal status of annexation.

\subsection{Institutional Network and Circular Causation}

A policy of economic restrictions was introduced in the aftermath of the 1967 Naksa, in order to maintain control and sustain the establishment of settlements in the captured areas. Israel's earliest economic strategy towards the oPt, the so-called Open Bridges, was led by then defense minister Moshe Dayan, who believed that positive economic spillovers would replace Palestinians' desire for political rights. He thus envisaged a plan to integrate the newly occupied territories as a captive market at Israel's own convenience (Van Arkadie, 1977; Arnon, 2007). The Open Bridges system curtailed trade flows with the rest of the world and enhanced bilateral exchanges with Israel, although with restrictions on highly competitive goods, such as agricultural products. As a result of the new trade course, non-durable goods started to be priced in Israeli lira, whilst long-term contracts such as installment plans and rental agreements remained denominated in dinars, partly due to the high downward pressure on the lira (Bregman, 1974). ${ }^{10}$ Palestinian workers were now also increasingly employed in Israel, such that the proportion of wages denominated in lira rose from 17 percent in 1969 to 36 percent on the eve of the Oslo process in 1992 (SAI, several volumes). While Military Order n. 31 assigned all taxation powers to the Israeli Defense Forces, all existing Arab banks and credit institutions were closed (Meron, 1983; Harris, 1988). Through Bregman (1974), Israel's Examiner of Banks reports that deposits, which amounted to 29 percent of GDP before 1967, represented only 4 percent in 1974. At this point, the few Palestinians who held accounts at Israeli banks were businesses and commuters that needed cross-border transfers, while most banking activities occurred through moneychangers intermediating for families split between the West Bank and Jordan (Pasch, 1992). Palestinian banking activity then revived in the mid-1980s when Israel allowed Arab banks to re-open in the oPt and completely replace Israeli branches.

To sum up, the Open Bridges system generated scope for a circular flow of money, whereby wages earned by Palestinians in Israel were then spent to purchase Israeli products or clear tax bills. Enforced connections in trade, labor and fiscal matters virtually obliged all sectors of Palestinian society to use Israel's medium of payment, to the extent that economic agents in the oPt would incur conversion costs if pricing in a currency other than that required by the coercive power. Thus, while on the one hand the process of currency internationalization was forcibly initiated by a colonial power, on the other hand it effectively reduced transaction costs across the currency's territorial domain, endogenously creating the

otherwise be opposed.

${ }^{10}$ Israel's currencies experienced frequent devaluations during the 1960s and 1970s. This trend culminated in the hyperinflation of the 1980s, following which the 1985 Economic Stabilization Plan was implemented and the new shekel introduced. 
optimal currency area that Mundellian economic theories were promoting at that time (Dellas and Tavlas, 2009). ${ }^{11}$

Then, in line with the view that money is a network good whose utility increases with the number of users, the persistence of existing monetary flows among private users prompted the government to officially adopt them with the 1994 Paris Protocol. Today, according to Article IV.10 of the Protocol, traded goods must be priced in shekels if exchanged either with Israel or through Israeli entry points, which is always the case. ${ }^{12}$ With regards to labor, Israel has progressively delinked itself from reliance on Palestinian workers: in 2018, about 13.3 percent of the West Bank's workers were legally employed in Israel or the settlements. Lost income from work in Israel has been replaced by shekel-denominated wages earned in the public sector, which presently provides one fifth of total jobs (PCBS, 2019). Furthermore, the customs union gives Israel sole control over the collection of import taxes and VAT, to be fully transferred to the PA on a monthly basis (Article III.15; Article VI), as well as the right to levy a tax on income earned by Palestinians in Israel (Article V). Although the PA is responsible for collecting direct taxes in the oPt, the contribution of the indirect duties collected by Israeli authorities exceeds 68 per cent of total PA tax revenue (Hamed, 2017).

As I put it, the common currency represents the thread that entwines distinct policy spheres established by the hegemonic power in a circular causation mechanism that is reinforced in each round, progressively building up a solid settler colonial architecture. In settler colonialism, 'invasion is a structure, not an event' (Wolfe, 2006, p. 388), which is erected by the hegemon to dissolve the native society and incorporate its productivity into a new colonial economic system. Expansion of the settler currency, driven by the settlers' invasion of the native economy, has effectively contributed to the displacement of indigenous social relations of production and exchange. In this context, currency internationalization can be viewed as the lubricant that greases the wheels of an institutional network (e.g. tax collection, an asymmetric customs union, dependency on remittances from Israel) used by the hegemonic state to demolish - rather than merely exploit - the natives' values and replace them with a settler society (Wolfe 2006, Veracini 2013).

\subsection{Competitive Forces and Cumulative Causation}

The persistence of circular mechanisms of causation among shekel-denominated trade, labor and fiscal transactions has expanded the currency's network externalities so far as to generate a process of hysteresis. The strengthening of shekelization in the oPt is demonstrated by its recent acceptance as storage of value. In the West Bank, use of the shekel for financial services started to accelerate in 2007, reaching 40 percent of total credit facilities and 33 percent of total deposits in 2017 (PMA, 2018). At the same time, the proportion of the PA's debt denominated in shekels grew from 25 per cent to 75.4 per cent (Hamed, 2017). The US dollar is still preferred for all banking activities taking place in the Gaza Strip and to hold less liquid assets such as time deposits and leases (PMA, 2018). The advance of financial shekelization must also be interpreted within the context of the balance of payments: the inherent stability of the new shekel, which was introduced in 1985 to replace a chronically weak old shekel, its persistent appreciation against the US dollar, which intensified in 2007,

\footnotetext{
${ }^{11}$ Based on pre-Oslo factor movements and on the similarity of their economic structures, Arnon and Spivak (1996) found that Israel and the oPt formed an 'optimal' monetary union (for a deeper study of this system, see also Arnon and Weinblatt, 2001; Naqib, 2003).

${ }^{12}$ Israel accounted for around 83 percent of Palestinian exports and 58 percent of imports in 2016 (PCBS, 2017).
} 
and the accumulation of excess shekel in the PMA reserves since 2007 have all significantly bolstered the asset substitution process (PMA, several publications). Most importantly, preferences for the shekel are driven by inertia as long as the exceptionally high level of uncertainty that characterizes life in the oPt "encourages a tendency toward what psychologists call mimesis: the rational impulse of risk-averse actors, in conditions of contingency, to minimize anxiety by imitative behavior based on past experience' (Cohen, 2003 , p. 6). In contrast with the orthodox view of an ergodic system adjusting around a steady state, shekelization follows a cumulative causation pattern that reflects the inherent tendency of the socioeconomic system to respond to a certain shock - in this case, the imposition of colonial rule - by generating further changes in the same direction.

Nevertheless, although circulation of a currency may intensify as a result of purely competitive supply and demand, it is the state that ultimately has to validate it (Palley, 2014). Market forces will always be subordinated to statecraft in that a certain common currency would only be able to facilitate those transactions and empower the institutions established by the hegemonic state. For example, considering that the internationalization of a top currency derives from the structural power of the market leader, one could say that dollarization urges international users of the US dollar to participate in the economic institutions established by the United States, thus exposing dollarized countries to the enormous competitive force of the market leader. Differently, given its colonial roots, shekelization seemingly exposes Palestinians to those institutions that hold in place the unilateral intromission and expansion of Israeli authority. In this case, the enforced expansion of the hegemon's currency can be viewed as a step beyond the neoliberal project, as the hegemonic apparatus forcefully seizes control of a polity's monetary policy not for the sake of self-correction and free markets, but to assist the subordination of the native society and land expropriation.

\section{What Implications for the Balance of Power?}

\subsection{Distributive Effects}

The internationalization of a currency affects the allocation of resources across the common currency area, depending on structural asymmetries that in turn reflect the rules of the game set by the hegemonic power - that is the country issuing the anchor currency (see Section 3.2). One of the largest redistributive effects of shekelization occurs via trade. On the one hand, enlargement of the hegemon's currency network paves the way for its products to access new markets. On the other hand, the fixed exchange rate commitment constrains the competitiveness of producers in weaker member countries. As of today, the PA is the fourth largest importer of Israeli goods and services, purchasing 6 percent of Israel's total exports (ICBS, 2017).

Goods exported from the oPt are not only uncompetitive due to an overvalued shekel, but are also fully monitored by Israeli military forces. As a matter of fact, political restrictions have always prevented businesses in the oPt from trading with third countries (Hanieh, 2002). Erickson von Allmen and Fischer (2001) present an empirical trade model for the $\mathrm{oPt}$, concluding that trade flows with Israel are not excessive if one accounts for the large effect of the currency union, but that trade with the rest of the world falls below the volume expected under existing bilateral agreements. According to a simple simulation by UNCTAD (2009), devaluing the currency would stimulate agriculture and manufacturing as exporting sectors, and be an effective import-substitution policy, with 'the potential of correcting the structural distortion of the economy' (p. 21). Instead, increased exposure to Israeli competitors due to a common currency and customs, along with rising production and transaction costs caused by 
foreign rule, has completely distorted the development process (Al-Bitawi, 2019). Today, less than 20,000 enterprises are active in the oPt, mainly confined to food, textiles, and a few manufacturers. A worrying pattern of structural change is visible in GDP composition: the value added of agriculture contracted by 11 percent in just one year (2016), while mining and quarrying (the largest manufacturing industries) declined by 21.3 percent (UNCTAD, 2017). In most domestic sectors, including utilities, the operative restrictions resulting from Israel's takeover cause the price level to increase more than in Israel (World Development Indicators, 2019). Although it must be noted that inflationary pressures in the West Bank and Gaza Strip are notably low compared to other Arab countries, when combined with rigid wages and low or negative real growth rates, they reduce real incomes (MAS, 2018).

An asymmetric currency union also ensures that the strong member has a structural employment advantage. Relatively high unemployment levels in the weak member make the wage rate lower than in the strong country, while the currency union opens up to free labor mobility. In fact, the economic infrastructure set up in 1967 with Open Bridges, and validated by the 1994 protocol, also benefits Israeli firms in obtaining relatively cheap natural and human resources from the Palestinian 'periphery.' For example, until the first intifada, Palestinians from the West Bank and Gaza Strip made up around 7 percent of the Israeli labor force, particularly in the construction and manufacturing sector: a phenomenon which enabled Mizrahi Jews to upgrade to supervisor positions (Hanieh, 2002).

At the same time, however, a Palestinian elite of investors has become able to thrive on the neoliberal and colonial model of production that derives from economic union with Israel, particularly the disempowered local labor force, the openness of markets, and the lack of political stability and institutions that can guarantee a safe and fair business ecology including access to raw materials and lack of restrictions on movement. This class is utterly 'dependent on its privileged relationship with Israeli capital' (Hanieh, 2002, p. 2) and so it has 'a material interest in the perpetuation of the political status quo' (Khalidi and Samour, 2011, p. 19).

Another positive implication envisaged by the New Keynesian literature is that in the presence of free capital mobility and a common currency, interest rates would eventually converge across countries (Dellas and Tavlas, 2009). Instead, evidence points to a huge discrepancy between prime interest rates in the oPt and Israel, which are respectively 3.5 and 7 percentage points (IFS, 2019). This is supposedly due to a mix of elements: (i) high country risk and a weak legal environment; (ii) the crowding-out effect resulting from the PA holding large amounts of shekel-denominated debt (PMA, 2018); and (iii) the fact that the effective money supply is determined by the balance of payment rather than the monetary authority. In the oPt, the current account deficit grew from $\$ 857$ million in 2000 to $\$ 2,140$ million in 2018, driven by excess imports that are only partly covered by work remittances and donor transfers (PCBS, 2019). Along with trade imbalances, net borrowing of foreign assets reached $\$ 1350$ million in 2018. With no control over money issuance, liquidity must be guaranteed by positive end-of-year net flows in the balance of payment; otherwise the monetary authority has to deploy its foreign exchange reserves in order to clear international payments. In the current circumstances, the PMA is unable to provide lender of last resort support to the economy: in 2018, international reserves covered only 7 percent of imports. On similar grounds, the South African Reserve Bank reimburses the rand seigniorage generated in other countries of the Rand Currency Zone, while also serving as a lender of last resort for all members.

In sharp downturns, foreign reserve depletion severely constrains the capacity of 
commercial banks to provide credit to the public. High lending rates further expose domestic agents to foreign exchange risk incurred by borrowing in other currencies (Hamed, 2017): the shekel loan-to-deposit ratio is around 50 percent, significantly below neighboring countries (PMA, 2019). Moreover, half of private sector credit is extended to private individuals for consumption and construction purposes, whilst the vast majority of small businesses remain underserved by the formal credit institutions, due to low physical collateral and other issues, leading them to rely on the informal financial sector (Hamed, 1998).

Essentially, the financial system developed under shekelization yields arbitrage opportunities for Palestinian financial intermediaries and moneychangers through currency conversion services and other forms of exchange rate manipulation (Qatrawi, 2015).

Moreover, those Israeli banks that are authorized by law to provide correspondent services ${ }^{13}$ to their Palestinian counterparts become better off as demand for their assistance expands. In addition, increased use of the common currency directly translates into seigniorage revenues for the issuing authority.

Shekelization also means that the PA's budget entirely depends on clearances, international transfers, tax revenues and access to local or external sources of credit. ${ }^{14}$ In this situation, public debt carries a 6 percent interest rate (IMF, 2018), which translates into a permanent contractionary fiscal stance and the incapacity to make independent decisions about the national economy. The World Bank's report (2018) warns about associated liquidity risks: 'Additional private sector arrears could further worsen the PA's fiscal situation as private companies run out of cash to pay their taxes to the government. An alternative option would be for the PA to not meet its wage commitments and its social transfers to the poorest of the population. Both options would risk social unrest. These options could also spill to the banking sector' (World Bank, 2018, p. 12). While persistently adverse circumstances for a member country may trigger balance of payment crises and possibly the end of the monetary union, shekelization in the oPt is enforced by foreign rule, and as such it cannot be reversed. In the presence of wage rigidity, internal devaluation occurs through unemployment in the domestic labor market.

Notably, many of these claims - for example, the crucial role of local elites - are common to other types of currency internationalization, while others accentuate the distinction between the different attributes of currency hegemony. The establishment of the European Monetary Union redistributed income and wealth according to market forces and redefined the pattern of trade and the composition of debt, harming the periphery of Europe until a disastrous crisis occurred in 2012. In postcolonial settings, a currency controlled by the hegemonic regime will also sustain the resource exploitation that the regime targets in the first place: in the CFA, the currency is overvalued to allow France to benefit from discriminatory contracts and trade arrangements, while foreign exchange reserves are held in Paris and reinvested by the French Treasury with no compensation paid to CFA member states (Taylor, 2019). Under settler colonialism, the use of the hegemon's currency will redistribute wealth and economic incentives to purposely create a system of economic distress, rather than exploitation, eventually compromising domestic governability, a crucial element to the settler state's reproduction.

\footnotetext{
${ }^{13}$ The government of Israel gave the Israel Discount Bank and Bank Hapoalim exclusive rights to provide financial services to Palestinian banks at a cost.

${ }^{14}$ As of today, the PA has not used the bond market as a source of finance.
} 


\subsection{Currency as a Coercive Tool}

The balance of power shifts further if the issuer state also holds a monopoly of the use of coercion within the international currency area, in which case the redistributive effects are amplified by other restrictions that may be inflicted upon the subordinate state. Furthermore, the more users rely on the hegemonic currency, the greater is the issuer's potential capacity to exercise leverage. In the oPt, given that the common currency contributes to expanding bilateral trade and labor flows (as evidenced in Section 3.2), the restricted regime of checkpoints and separation barriers ${ }^{15}$ arbitrarily established by Israel in the oPt since 1993 is more effective in restraining movement of goods and people under the current monetary arrangement than it would be otherwise.

A more direct instance of the use of currency power for retaliation took place in mid-2007 after Hamas seized control of the Gaza Strip, upon which Israel and the United States declared it 'hostile territory.' This move suddenly left Bank Hapoalim and Discount Bank the two commercial banks previously appointed by the government of Israel to hold correspondence services with the oPt - open to potential litigation (Wazir et al., 2011). In light of the severe legal risks they were incurring by providing ordinary financial services to their counterpart, the two Israeli correspondents decided to fully suspend check clearance and cash transfers directed to the Gaza Strip. For analogous reasons, the Israeli military repeatedly refused to allow shekel notes and coins from banks in the West Bank to reach their own Gaza Strip branches via armored convoys (Wazir et al., 2011). Similarly, in 2006, Palestinian Prime Minister Haniyeh was arrested at the Rafah crossing with Egypt to prevent him from bringing in about \$30 million in aid from neighboring Middle Eastern nations (Palestine Papers, 2006a). The unilateral decision to prevent large sums of cash passing through crossing points had no reasonable grounds, as the PMA had strengthened supervision with anti-money laundering regulations and the Palestinians were applying 'official procedures for declaring the money brought in' (Palestine Papers, 2006b). The Palestine Papers (2006b) also reveal the silent consensus of the European Union mission at the Gaza border, which had to ensure smooth implementation of the bilateral agreements. By prompting the correspondent banks' decision to halt the system of transfers, the Israeli government created a way of involving non-state actors in the marginalization of Palestinians (Palestine Papers, 2007). In contrast to the Gaza Strip, banks in the West Bank have been accumulating shekel surpluses since 2009, due to the Bank of Israel refusing cash transfers in violation of mutual agreements. In fact, according to Article IV of the Paris Protocol, the PMA has the right to convert excess shekel received from banks operating under its jurisdiction into any foreign currency traded by the Bank of Israel, up to amounts determined for each period by the balance of payments. On a similar note, in the wake of the PA's reconciliation with Hamas in 2014, the government of Israel reduced the maximum amount of shekels to be deposited at Israeli banks by their Palestinian counterparts. Although the Protocol provides no deposit ceiling, the government decision entailed refusal by the Israeli banking system to receive shekel surplus (PMA, 2014). Amid media attention and fears of PA collapse and social unrest, in early 2017 Israeli authorities granted Israeli correspondent banks a two-year immunity from potential lawsuits involving cases of terror financing, as well as starting discussions over the possibility of shifting correspondent services to a state-owned agency, assuming this would eliminate the

\footnotetext{
${ }^{15}$ Israeli occupation policies are varied and complex. They consist in the imposition of unbalanced relations as the normal state of affairs and retaliatory sanctions in the event of direct confrontation between the parties. The latter include the expropriation of Palestinian land, water, and other resources, the construction of Jewish settlements in the West Bank, the dismantling of Palestinian institutions, the Israeli veto on new Palestinian investments, and the siege of Gaza.
} 
risk attached to cross-border financial flows. ${ }^{16}$ Yet, during 2018, the cash surplus in the West Bank reached NIS 5.6 billion (PMA, 2019).

In the only study that deals with this issue, Toffano and Yuan (2019, thereafter TY), claim that 'these threats reflect a complex interplay of legal and economic, domestic and international factors' (p. 8) - and so they propose a technically advanced solution that would protect cross-border payments between the West Bank and Israel from disturbing elements. ${ }^{17}$ Namely, TY design 'a private permissioned ledger owned and supervised by the PMA and the Bank of Israel, where Israeli and Palestinian banks can exchange e-shekels backed 1:1 by shekel deposits held at the co-agency.' While the ledger would eliminate the single point of failure by allowing every user to occupy a node of the platform and be legally accountable, it completely misconceives the political nature of economic institutions and relations between the government of Israel and the PA. Rather than recognizing Israel's structure of colonialism as the source of the problem and, as such, dismantling it, the mechanism designed by TY implicitly accepts the status quo and guarantees its continuation by creating 'occupationcircumventing' conditions - in this case, for the survival of cross-border capital flows. Depoliticizing economic matters is tantamount to reproducing the political factors that caused the issues in the first place. With TY's system normalizing Israel's hegemony, the burden of adjustment falls once again on Palestinians, who must use their own resources to endow the incumbent regime with the private information ${ }^{18}$ necessary for the maintenance of power. On another note, the technical trick still needs the hegemon's compliance to bypass 'legal and economic' obstacles: 'If suspicious transactions are detected, supervisory nodes can share the information with the relevant nodes' (p. 34). So, although accountability is shifted to individual agents and the single point of failure is eliminated, the government of Israel is ultimately allowed to arbitrarily halt specific exchanges for 'security concerns' through the supervisory node held at its central bank. ${ }^{19}$

Although Israel agreed to serve as clearinghouse for the Palestinians (Article IV.10-15 PP, 1994), it has always acted in opposition to the rule of law, therefore raising typical cooperation issues. Undoubtedly, the situation portrayed above is uncommon in the world of central banking and monetary unions: by repeatedly preventing the Bank of Israel from purchasing excess stock of shekels from the oPt, the state has refused to validate its own currency as a means of debt - resulting in a series of excess liquidity-associated costs (PMA, 2014). In essence, whether the political circumstances and the diplomatic relations between

\footnotetext{
${ }^{16}$ Additional evidence of currency pressure exists: (i) before the first Intifada, the Bank of Israel repeatedly refused to convert Palestinian banks' excess Jordanian dinars into shekels (Pasch, 1992); (ii) after the second Intifada, the government of Israel refused Palestinian membership of the Israeli clearing house, halting the settlement of cross-border payments; (iii) in 2011, the Bank of Israel capped liquidity transfers at $\$ 120$ million/month (MAS, 2019).

${ }^{17}$ TY (2019) completely ignore the Gaza Strip, contributing to the dominant narrative of geopolitical fragmentation and separated Palestinian identities.

18 'The possibility to get full visibility on all transactions allows supervisory nodes to continuously monitor what is happening on the ledger' (Toffano and Yuan, 2019, p. 34).

${ }^{19}$ Another issue associated with TY's technology is related to the fact that: 'Movement of collateral may still be needed. [...] Excess NIS cash in Palestinian banks' vaults could be used as collateral backing the e-shekels' (p. 34). E-shekels overcome physical barriers, but still depend on the Bank of Israel for supply of physical shekels.
} 
Israel and PA leaders are changed with respect to the early 1990s should never affect the provision of services vital to society.

History provides some useful lessons about the dangerous link between adverse politics and currency relations. The clearest evidence is provided by Panama - a country that has been using the US dollar as legal tender since 1904, and which analogously to the oPt underwent episodes of political crises with its nominal anchor. In 1988, as part of its campaign of opposition to the Noriega regime, the United States government froze Panamanian bank deposits in the US and cut off the supply of new paper currency to Panama. Goldfajin and Olivares (2000) assert that dollarization made the disruption worse and that the resulting liquidity shortage in Panama contributed directly to the weakening of Noriega. At the same

time, Panama's experience illustrates how a dollarized country was successful in withstanding political adversity by operating large budget deficits and maintaining a special relationship with the IMF. Along the same lines, Helleiner (2010) evokes the Cuban financial crisis of 1920, when United States banks in Cuba were 'in a dominant position after their Cuban counterparts collapsed without access to foreign emergency funds' (p. 422). The Cuban experience suggests that it is not so obvious that international financial institutions would be willing to accommodate the requests of economies in trouble if they do not play a key geopolitical role like Panama. The Palestinian case goes even further, demonstrating that the monetary dependence established by the hegemonic state can be systematically used as a coercive tool to sustain the strategic goals of the settler colonial project. Moreover, Israel's repressive currency policy has not been deployed in the form of a single event, but rather as a constant and ongoing threat that repeatedly materializes to reinforce the broader political strategy.

\section{The Way Out}

As evidenced so far, the entrenchment of policies aimed at depressing the Palestinian economy, the currency's network effects and particular interests have contributed to constitute the present scenario to the point where alternative monetary systems seem to be detached from reality. At the same time, despite the incremental diffusion of the shekel, it emerges that Palestinians have never completely foregone the use of the dollar as a store of value or the dinar as a unit of account. While the dollar is the most internationally marketed currency, in the oPt the dinar stems from a colonial legacy, but since 1968 its use has not borne political implications, and as such it is accepted by the Palestinian community. In contrast, the shekel has been derided as symbolizing foreign rule, with a public call to write 'Free Palestine' on Israeli currency notes. The campaign collapsed soon after Palestinian banks announced that they would refuse to accept the damaged banknotes for fear that Israeli correspondent banks would do the same. In line with the State theory of money, there is no way to refuse the sovereign's money as long as the authority holds institutional control and only accepts its own coins and banknotes. Fuller (2009) recalls how Africans attempted subversive measures against British authority such as 'using indigenous and foreign currencies, counterfeiting colonial coins and banknotes, defacing currency, melting down money to make jewelry, and refusing to use bank notes' (p. 60) but they eventually had to claim political independence to get full monetary sovereignty.

In general, efforts to correct the currency arrangement prior to the other structural distortions would prove inadequate as an instrument to dismantle the broader settler colonial architecture, of which shekelization is only a single component. By opposite arguments, it is legitimate to posit that loss of Israeli hegemony would likely cause Palestinian trade and labor 
flows to divert to Arab countries and Europe (Cobham, 2004), ${ }^{20}$ thus loosening structural ties with the shekel. While an independent Palestinian economy does not necessarily tend towards shekelization, abandoning the shekel will not guarantee independence. At the same time, shekelization must be acknowledged as an integral component of the settler colonial economic structure if one is to unequivocally dismantle it. Political independence without economic liberation would leave a situation of internal colonialism, as in South Africa. Another crucial factor in the mainstream discussion of shekelization irreversibility is financial actors' lack of confidence in the PMA's commitment and capability to maintain the stability and convertibility of a national currency. As cumulative causation processes would lead one to expect, prolonged instability and external dependence have become structural to the point that neoliberal solutions that minimize the role of the state, such as shekelization, are currently advertised as unavoidable.

Recently, digital currencies have gained real credence as potential rivals to paper currency and coins. Sovereign digital currencies are at the center of discussion in central banks around the world as an alternative medium of exchange that is universally accessible, virtually costless, and fully tracked so as to allow transparent conduct of monetary policy. But national digital currencies are also considered by authorities in the developing world as a way of reducing the diffusion of the US dollar, as in the Marshall Islands. In 2018, cash-strapped Venezuela launched an oil-backed crypto-currency precisely to attract foreign assets in the face of US sanctions. But critiques claim that the Venezuelan Petro is not perceived as a credible tool in view of the persistent inability of the public authorities to control the country's debt and inflation, as well as the government's continued ability to manipulate the currency's value. Interestingly, in March 2018, US President Trump reacted by signing a national ban on the use of any Venezuelan government-issued crypto-currency. The PA itself cautiously announced it had been working on a digital currency to dodge Israeli restrictions, and the plans have recently become firmer. Previous examples show that for a digital technology to be effectively instrumental in empowering the Palestinian struggle, it must be credible in the face of financial markets. This will happen only when the structural trade deficit is significantly reduced; otherwise the PMA would be forced to progressively devalue an independent currency to sustain international payments. Beyond the importance of central bank credibility for newly-issued currencies, another condition if an independent digital technology is to represent a real alternative to the Israeli shekel is the formation of a durable market outside the influence of the hegemonic state which will sustain demand for the new currency as an everyday payment system. To this purpose, it is imperative that the PA forges cooperative relations with holders of power around the world who also embrace the currency's radical meaning. Most importantly, recognizing that these economic phenomena are ultimately political processes implies that they can be reversed by simply challenging the legitimacy of the project and changing the prevailing culture: 'In this sense, the lack of 'ability to see and conceive alternatives' is a form of psychological domination. People follow a direction because they mistakenly think that no other possibilities exist' (Hanieh, 2016, p. 36).

\footnotetext{
${ }^{20}$ The PA has signed FTAs with Jordan (1995), Egypt (1997), the EU (1997), the USA (1997), GAFTA (1997), and Turkey (2004). Nonetheless, Israeli movement restrictions and discrimination against Palestinian products at the points of access have resulted in minimal utilization of extraregional agreement. Cobham (2004) employs a gravity model to estimate the trade patterns of the future Palestinian state, and finds that the largest share of trade is likely to be with the European Union.
} 


\section{Concluding Remarks}

This paper has attempted to disentangle the nexus between currency policy and settler colonialism by exploring the origins and implications of the use of the Israeli currency in the oPt through the lenses of the State and Credit theories of money. The historical account showed that the original decision to adopt the shekel was not based on a rational calculus of strictly economic costs and benefits. Instead, the diffusion of the Israeli currency across Palestine has always been intrinsically associated with the spatial expansion of Israel's hegemony. Section 3 also revealed how the complex interplay of settler-colonial institutions involving trade, labor, and fiscal ties forcefully forged by the hegemonic power to intrude on and dispossess the native economy is strictly related to the existence of a common currency network in a mutual and circular causation mechanism.

Having established that monetary hegemony goes hand-in-hand with geopolitical power, dismantling the political implications of this particular case of currency internationalization seems of prime importance. First, it preserves structures of production and exchange that bolster the economic interests of the colonial power and secure privileges for its national bourgeoisies and the elites that intermediate with the captive economy. Second, a settler colonial currency masked by goodwill and credibility is detrimental to the export of competitive products, job creation, and the fight for independence. In this respect, what needs to be emphasized is that the adoption of a foreign currency is a neoliberal policy in that it severely reduces public sovereignty over monetary tools. However, rather than subsidizing global competitive forces, as is the case with top currencies like the US dollar and euro, it permits a settler society and its powerful stakeholders to dispossess the native economy of sovereignty. Certainly, the dynamics of settler colonial projects cannot be reduced exclusively to monetary hegemony ${ }^{21}$ but the latter's specific contribution to facilitating the transfer of resources from the periphery to the core of the currency area, thereby reinforcing the dependency paradigm and facilitating land dispossession, is significant. Similarly, even if political strife draws upon other sectors of life more than monetary policy, the cross-border banking and monetary system that develops around the hegemonic currency is systematically used as a coercive tool to sustain the strategic goals of the settler colonial project. In line with the evidence that Israel's political agenda has been expedited by the enforced shekelization of the oPt, the latter has been placed at the untouchable core of Israel's economic program since the outset of the occupation in 1967. Finally, it is also argued that the shekel can serve as a means of payment in the Palestinian economy of the West Bank and Gaza Strip as long as the Bank of Israel's operations remain independent of the government's political ends. On the same lines, the political abuse of currency hegemony is likely to disrupt the whole system through a liquidity crisis. It follows that, under the present circumstances, endorsing shekelization as an unavoidable state of affairs or as the best possible monetary arrangement is a harsh blow to Palestinian national liberation.

This paper substantially challenges the unapologetic belief, repeatedly promoted by international organizations and a strand of economic theorists, that small and open economies with fragile institutions should always delegate their monetary sovereignty to a conservative central bank. Although explored through the Palestinian monetary experience, these arguments apply to any case in which the issuer country is pursuing territorial expansion over land already inhabited by an indigenous community. Suffice it is to say that any quasi-state

\footnotetext{
${ }^{21}$ Examining in detail how development has been diverted within the rule set by Israel for the exclusive benefit of a rentier class is out of the scope of this paper. See Van Arkadie (1977), Roy (1999), Hanieh (2002), and Taghdisi-Rad (2011) for a full account of this topic from different angles.
} 
with no national money conveniently uses the currency issued by a country that is willing to exercise no market restriction such that potential disagreements with the colonial power do not interfere with monetary matters (Northern Cyprus, South Ossetia and Abkhazia, and the Sahrawi Arab Democratic Republic are all examples). The currency internationalization enforced in a captive country as part of a settler colonial project not only acts as a barrier to industrialization and economic liberation in line with hegemonic institutions, but also offers a sophisticated tool for coercion that directly assists the hegemon's political ends. It follows that a settler currency represents a multifaceted vehicle that facilitates a process of economic extraction and distress that over time consolidates the existing imbalance of power in a way that allows the settler state's reproduction.

\section{Disclosure statement}

No potential conflict of interest was reported by the author.

\section{References}

Al-Bitawi, W. (2019). Developing Competitiveness and Increasing the Share of National Products: Food Sector. Palestine Economic Policy Research Institute (MAS).

Armstrong, V., Boyd, C., \& Gardner, N. (2007). Selection of a Currency regime for Palestine, International Business \& Economics Research Journal, 6(6).

Arnon, A. (2007). Israeli Policy Towards the Occupied Palestinian Territories: The Economic Dimension 1967-2007. Monaster Center for Economic Research Ben-Gurion, University of the Negev Discussion Paper, 07(13).

Arnon, A., \& Bamya, S. (2015). Economics and Politics in the Israeli Palestinian Conflict. The AIX Group.

Arnon, A., \& Spivak, A. (1996). Monetary Integration between the Israeli, Jordanian and Palestinian Economies. Ben-Gurion University of the Negev Discussion Paper, 95(11).

Arnon, A. , \& Weinblatt, J. (2001). Sovereignty and economic development: the case of Israel and Palestine, The Economic Journal, 111(472), F291 - F308.

Barro, R. J., \& Gordon D. B. (1983). Rules, Discretion and Reputation in a Model of Monetary Policy. Journal of Monetary Economics, 12(1), 101-121.

Beidas, S., \& Kandil, M. (2005). Setting the Stage for a National Currency in the West Bank and Gaza: The Choice of Exchange Rate Regime. IMF Working Paper 05/70.

Bregman, A. (1974). Economic Growth in the Administered Areas, 1968-1973. Bank of Israel, Research Department.

Broz, J. L., \& Frieden, J. (2001). The Political Economy of International Monetary Relations. Annual Review of Political Science, 4, 317- 343.

Cobham, D. (2004). Alternative Currency Arrangements for a New Palestinian State. In D. Cobham \& N. Kanafani (Eds.) The Economics of Palestine: Economic Policy and Institutional Reform for a Viable Palestinian State. London: Routledge. 
Cohen, B. (2003). Monetary Union. The Political Dimension. In D. Salvatore, J. W. Dean, \& T. D. Willett (Eds.) The Dollarization Debate. New York: Oxford University Press.

Cohen, B. (2015). Currency Power: Understanding Monetary Rivalry. Princeton and Oxford: Princeton University Press.

Dellas, H., \& Tavlas, G. (2009). A Optimum Currency Area Odyssey, Bank of Greece, Economic Research Department.

Erickson von Allmen, U., \& Fischer, F. (2001). The choice of future exchange rate regime in the West Bank and Gaza. In Valdivieso, R., U. Erickson von Allmen, G. J. Bannister, H. R. Davoodi, F. Fischer, E. Jenkner, \& M. Said (Eds.) West Bank and Gaza: Economic Performance, Prospects and Policies. Washington DC: IMF.

Fields, D., \& Vernengo, M. (2013). Hegemonic Currencies during the Crisis: the Dollar versus the Euro in a Cartalist Perspective, Review of International Political Economy, 20(4), 740-759.

Frieden, J. (2003). The Political Economy of Dollarization: Domestic and International Factors, in E. Levy-Yeyati \& Sturnzenegger F. (Eds.) Dollarization: Debates and Policy Alternatives. Cambridge, MA: MIT Press.

Fuller, H. (2009). From Cowries to Coins: Money and Colonialism in the Gold Coast and British West Africa in the Early 20th Century. In C. Eagleton, H. Fuller, \& J. Perkins (Eds.) Money in Africa, 54-61. London: British Museum Research Publications.

Khalidi, R., \& Samour, S. (2011). Neoliberalism as Liberation: The Statehood Program and the Remaking of the Palestinian National Movement. Journal of Palestine Studies, XL(2), $6-25$.

Kirshner, J. (1995). Currencies and Coercion. Princeton: Princeton University Press.

Goldfajin, I., \& Olivares, G. (2001). Full Dollarization: the Case of Panama. Economia, $1(2), 101-155$.

Goodhart, C. (1998). The two Concepts of Money: Implications for the Analysis of

Haddad, T. (2016). Palestine LTD: Neoliberalism and Nationalism in the Occupied Territory. London and New York: I. B. Tauris.

Hamed, O. (1998). Informal Finance and Lending NGOs in the West Bank and Gaza Strip. Palestine Economic Policy Research Institute (MAS) Discussion Paper.

Hamed, O. (2017). Government Borrowing and Liquidity and the Stability of the Palestinian Banking System. Palestine Economic Policy Research Institute (MAS) Discussion Paper.

Hanieh, A. (2002). Class, Economy, and the Second Intifada. Monthly Review, 54(5).

Hanieh, A. (2008). Palestine in the Middle East: Opposing Neoliberalism and US Power. Monthly Review MRZine. 
Hanieh, A. (2016). Development as Struggle: Confronting the Reality of Power in Palestine. Journal of Palestine Studies, 45(4), 32-47.

Harris, L. (1988). Money and Finance with Undeveloped Banking in the Occupied Territories. In G. Abed (Ed.) The Palestinian Economy: Studies in Development under Prolonged Occupation. London and New York: Routledge, 191-223.

Helleiner, E. (2003). Dollarization Diplomacy: US policy towards Latin America coming full circle?, Review of International Political Economy, 10(3), 406-429.

Henry, J. F. (2004). The Social Origins of Money: The Case of Egypt. In L. R. Wray (Ed.) Credit and State Theories of Money: The Contributions of A. Mitchell Innes. Cheltenham and Northampton: Edward Elgar.

ICBS (1968 - 1996). Statistical Abstract of Israel. ICBS.

IMF (2018). West Bank and Gaza: Report to the Ad Hoc Liaison Committee. IMF.

Ingham, G. (2004). The Nature of Money. Malden: Polity Press.

Israel Defense Forces (1967). Military Orders Number 13, 31, 34, 41, 76, 83 and 89.

Knapp, G. (1924). The State Theory of Money. London: MacMillan \& Company Limited.

Levin, J. (2007). Accord to Discord: A Political Economy Approach to the Oslo Process, Palestine-Israel Journal of Politics, Economics \& Culture, 14(3), 62-69.

McNamara, K. (2008). A rivalry in the making? The Euro and International Monetary Power, Review of International Political Economy, 15(3), 439-459.

Meron, R. (1983). Economic Development in Judea-Samaria and Gaza District, 1970-80. Bank of Israel, Research Department.

Mitchell-Innes, A. (1914). The Credit Theory of Money. The Banking Law Journal, 31, 151-168.

Myrdal, G. (1957). Economic Theory and Underdeveloped Regions. London: University Paperbacks, Methuen.

Moore, B. J. (1988). Horizontalists and Verticalists: The Macroeconomics of Credit Money. Cambridge University Press.

Mwangi, W. (2002). The Lion, the Native and the Coffee Plant: Political Imagery and the Ambiguous Art of Currency Design in Colonial Kenya, Geopolitics, 7(1), 31-62.

Naqib, F. (2003). Economic Aspects of the Palestinian - Israeli Conflict: the Collapse of the Oslo Accord. Journal of International Development, 15(4), 499-512.

Ottensooser, R. (1955). The Palestine Pound and the Israel Pound; Transition from a Colonial to an Independent Currency. Geneva: E. Droz.

Palestine Papers (2006a). Minutes from 'Coordination and Evaluation Committee' meeting 
with EUBAM. Al-Jazeera.

Palestine Papers (2006b). Agenda for the 4th 'Coordination and Evaluation Committee' meeting at the Delegation of the European Commission. Al-Jazeera.

Palestine Papers (2006c). Letter to Colonel Vogl from Erekat re: 'Required Reporting of Transfers of Money through the Rafah Crossing Point.' Al-Jazeera.

Palestine Papers (2007). Agenda for the 7th 'Coordination and Evaluation Committee' meeting at the Delegation of the European Commission. Al-Jazeera.

Palestine Papers (2008). Letter to Mr. Makepeace from Erekat re: 'Status of Reserves of the Palestine Currency Board from 1948.' Al-Jazeera.

Palley, T. (2014). Money, Fiscal Policy, and Interest Rates: A Critique of Modern Monetary Theory. Review of Political Economy, 27(1), 1-23.

Paris Protocol on Economic Relations between the Government of Israel and the P.L.O., representing the Palestinian people (1994). In Gaza-Jericho Agreement Annex IV. Jerusalem: Israel Ministry of Foreign Affairs.

Pasch, P. (1992). Monetary Dualism: The Financial Sector of the West Bank, 1967-1989. University of Haifa Department of Publication.

PCBS (1996 - 2019). Several Publications, Ramallah.

PMA (2009 - 2017). Financial Stability Report, Ramallah.

PMA (2019). Statistics. www.pma.ps (accessed on 17 March 2019).

Qatrawi, I. (2015, July 31). Gaza Money Traders Profit from Dollar - Shekel Exchange Rate Manipulations. Al-Monitor. www.al-monitor.com/pulse/originals/2015/07/palestinegaza-money-exchange-rates-shekel-dollars-banks.html

Robinson, J., Acemoglu, D., \& Johnson, A. (2005). Institutions as a Fundamental Cause of Long-Run Growth. Handbook of Economic Growth, 1A, 386-472

Roy, S. (1999). De-development Revisited: Palestinian Economy and Society Since Oslo. Journal of Palestine Studies, 28 (3), 64-82.

Saad-Filho, A. (2010). Growth, Poverty and Inequality: From Washington Consensus to Inclusive Growth. DESA Working Paper, 100.

Sadeh, T. (1997). The Economic Desirability of Middle-Eastern Monetary Cooperation, The World Economy, 20(6), 809-827.

Strange, S. (1971). The Politics of International Currencies. World Politics, 23(2), 215-231.

Taghdisi-Rad, S. (2011). The Political Economy of Aid in Palestine: Relief from Conflict or Development Delayed?. Political Economy of the Middle East and North Africa Series. London: Routledge. 
Taylor, I. (2019). France à fric: the CFA Zone in Africa and Neocolonialism. Third World Quarterly, 40, 1064-1088.

Toffano, P., \& Yuan, K. (2019). E-Shekels Across Borders: a Distributed Ledger System to Settle Payments between Israel and the West Bank. LSE Middle East Centre Paper Series, 26.

UNCTAD (2009). Policy Alternatives for Sustained Palestinian Development and State Formation, UNCTAD/GDS/APP/2008/1. UNCTAD.

UNCTAD (2017). Report on UNCTAD Assistance to the Palestinian People: Developments in the Economy of the Occupied Palestinian Territory. TD/B/64/4. UNCTAD.

Wazir, J. K., Atallah, M., \& Sarsour, S. (2011). From Occupation to an Independent Monetary Policy. In D. Cobham \& G. Dibeh (Eds.), Money in the Middle East and North Africa. New York: Routledge.

Wolfe, P. (2006). Settler Colonialism and the Elimination of the Native. Journal of Genocide Research, 8:4, 387-409.

World Bank (1993). Developing the Occupied Territories: an Investment in Peace, Volume II. Washington, D.C.: World Bank Group.

World Bank (2002). Long Term Policy Options for the Palestinian Economy. Washington, D.C.: World Bank Group.

World Bank (2018). Economic Monitoring Report to the Ad Hoc Liaison Committee. Washington, D.C.: World Bank Group.

World Development Indicators [dataset]. https://datacatalog.worldbank.org (accessed on 1 March 2020).

Van Arkadie, B. (1977). The Impact of the Israeli Occupation on the Economies of the West Bank and Gaza. Journal of Palestine Studies, 6(2), 103-129.

Veracini, L. (2013). 'Settler Colonialism': Career of a Concept. Journal of Imperial and Commonwealth History, 41(2), 313-333. 